\title{
Erythropoietin Production by Macrophages from Preterm Infants: Implications Regarding the Cause of the Anemia of Prematurity
}

\author{
ROBIN K. OHLS, YAN LI, MICHAEL S. TRAUTMAN, AND ROBERT D. CHRISTENSEN \\ Division of Human Development and Aging. L'niversity of L'tah School of Medicine, Salt Lake ('ity. L'tah \$41.32
}

\begin{abstract}
In the human fetus, liver macrophages appear to be the primary source of erythropoietin (Epo). Epo production shifts from the liver to peritubular cells in the kidney sometime during the 3rd trimester. Some preterm infants experience a hyporegenerative anemia that appears to be caused by inadequate Epo production. It is not clear whether this anemia is due to deficient Epo production by liver macrophages or renal peritubular cells. To assess this situation, we measured Epo mRNA and protein in macrophages obtained from cord blood of preterm and term infants and from peripheral blood of adults. Macrophages from preterm infants generated Epo mRNA and protein as effectively as those from term infants and adults. It appears that the anemia of prematurity is not due to defective Epo production by macrophages. (Pediatr Res 35: 169-170, 1994)
\end{abstract}

Abbreviation

Epo, erythropoietin

Infants born prematurely may experience a prolonged hyporegenerative anemia, sometimes referred to as "the anemia of prematurity" (1). This normocytic, normochromic anemia often becomes apparent by the $3 \mathrm{rd}$ or 4 th postnatal wk. Although some infants tolerate this condition without apparent difficulty, others demonstrate signs of anemia, such as an elevated heart rate, an increasing blood lactate concentration, and poor growth (2). The anemia of prematurity is characterized by inappropriately low serum concentrations of Epo (3), yet the underlying molecular mechanism responsible for the reduced Epo production remains undefined.

Zanjani et al. (4) showed the liver to be the primary source of Epo production in the fetus. They also determined that the anatomic site of Epo production shifts from the liver to the peritubular cells of the kidney sometime between the late $3 \mathrm{rd}$ trimester and the 1 st mo of life. With immunoflorescent photomicroscopy, Gruber et al. (5) localized Epo production to macrophages within the fetal liver.

It is unknown whether preterm infants rely on Epo produced by the liver, the kidney, or a combination of the two. The anemia of prematurity, therefore, might result from diminished production of Epo from liver macrophages or, alternatively, from a failure to initiate production of Epo in the kidney. As an initial model to evaluate macrophages from preterm infants, we devised

Received July 15. 1993; accepted September 30. 1993.

Correspondence: Robin K. Ohls, M.D.. Division of Neonatology. University of Florida College of Medicine. P.O. Box 100296. JHMHC. Gainesville, FL 326100296.

Supported by Grants HD-00988. HL-44951 and RR-00064 from the National Institutes of Health. studies to test whether circulating cord blood macrophages obtained from preterm infants could transcribe the Epo gene and assemble and export Epo protein as well as macrophages from term infants or from adults.

\section{MATERIALS AND METHODS}

Light-density mononuclear cells were isolated from the umbilical cord blood of five preterm (26 to $32 \mathrm{wk}$ gestation) and five term ( 37 to $40 \mathrm{wk}$ gestation) infants. and from the peripheral blood of five adults (6). The cells were cultured in $\alpha$-minimum essential medium (Sigma Chemical Co., St. Louis, MO) with $1 \%$ nutridoma (Boehringer Mannheim, Indianapolis. IN), and incubated with plateau concentrations of recombinant macrophage colony stimulating factor $(25 \mathrm{mg} / \mathrm{L}$. R and D Systems. Minneapolis, $\mathrm{MN}$ ), and recombinant granulocyte macrophage colony stimulating factor $(2 \mathrm{mg} / \mathrm{L}, \mathrm{R}$ and D Systems) to support the development of progenitor cells and monocytes into a macrophage phenotype. After $7 \mathrm{~d}$ of culture, the plates were washed of nonadherent cells, and new media, without additional growth factors, were added. The proportion of macrophages in the population was determined by $\alpha$-naphthyl-esterase staining (Sigma). The adherent macrophages were incubated for $24 \mathrm{~h}$ in either $1 \%$ or $21 \%$ oxygen environments. Oxygen determinations were made before and after incubation using a Hudson oxygen analyzer. Hep 3B cells (a human hepatoma cell line known to increase Epo production under hypoxic conditions) were used as a positive control ( 7 ).

Media were collected after the 24-h incubation period and Epo protein concentration quantified by ELISA ( $R$ and D Systems). The cells were lysed with guanidinium thiocyanate, and total RNA was extracted using a rapid acid-phenol chloroform method (8). The RNA was then reverse transcribed, and the resulting cDNA was amplified by polymerase chain reaction.

Primers for the Epo gene were chosen to span an intron, using a computerized primer selection program (DNA Stridor 1.0. Departement de Biologie, Cerex. France). Amplification of Epo cDNA would yield a 235-bp product, whereas amplification of contaminating genomic DNA (including the 133-bp intron) would yield a $368-b p$ product. The RNA samples were reverse transcribed with MMLV reverse transcriptase (Bethesda Research Laboratories, Gaithersburg. MD), and the DNA was amplified in a DNA thermal cycler for 30 cycles with Taq polymerase (Perkin-Elmer, Norwalk, CT). The polymerase chain reaction products were run on an ethidium bromide-stained agarose gel (FMC BioProducts, Rockland, ME) and photographed.

\section{RESULTS}

After $7 \mathrm{~d}$ of culture, macrophages accounted for more than $99 \%$ of the cells in the culture plates. Epo mRNA was detected in preterm, term, and adult macrophages (Fig. 1). No bands corresponding to contaminating genomic DNA were observed. 


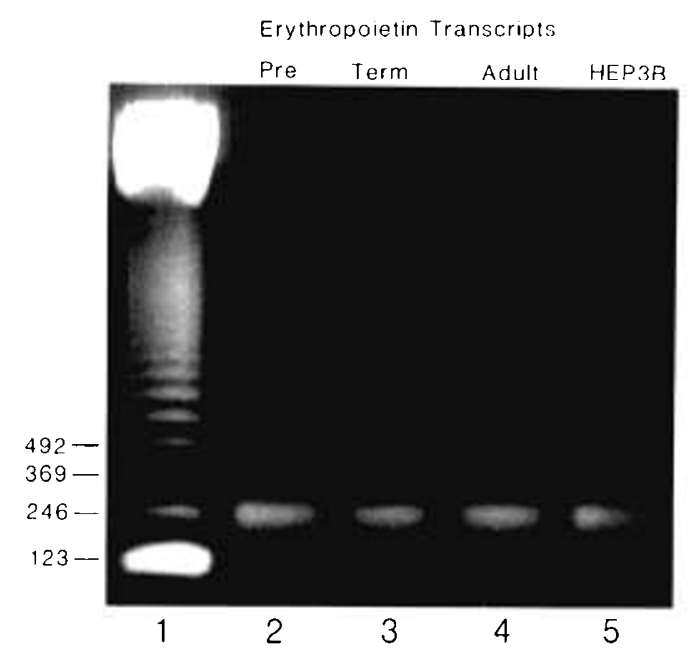

Fig. 1. Epo cDNA (235 bp) reverse-transcribed from Epo mRNA obtained from preterm (lane 2), term (lane 3 ), and adult (lane 4 ) samples. No contaminating genomic DNA bands $(368 \mathrm{bp})$ were seen in any of the samples. Transcripts of Epo cDNA from Hep 3B cells are shown in lane 5 as a positive control.

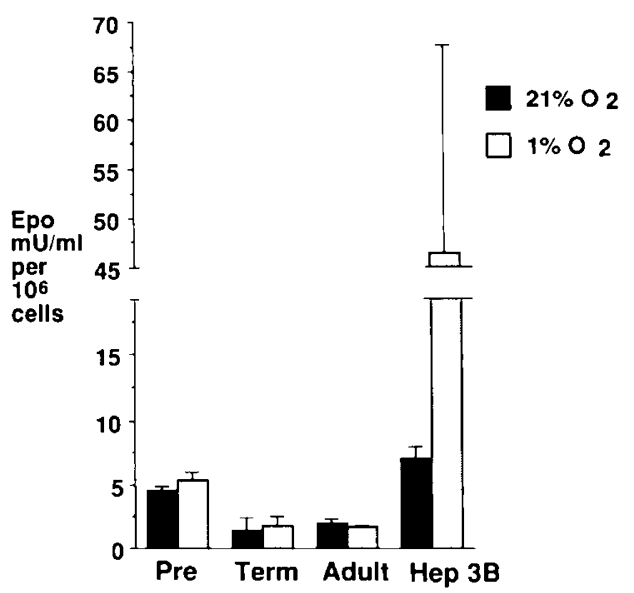

Fig. 2. Epo (milliunit per milliliter or units per liter) protein accumulation (mean $\pm S E M$ ) in supernatants of preterm, term. and adult macrophages, and in Hep 3B cells. Cells were incubated for $24 \mathrm{~h}$ in $21 \%$ (solid hars) or $1 \%$ (shaded hars) oxygen environments.

Figure 2 shows Epo protein accumulation in supernatants of macrophages from preterm and term infants, adults, and Hep $3 B$ cells. Macrophages from preterm infants accumulated 4.58 $\pm 0.29 \mathrm{mU} \mathrm{Epo} / \mathrm{mL} / 10^{6}$ cells $(4.58 \pm 0.29 \mathrm{U} / \mathrm{L})$, compared with $1.44 \pm 0.97 \mathrm{mU} / \mathrm{mL} / 10^{6}$ cells $(1.44 \pm 0.97 \mathrm{U} / \mathrm{L})$ from term cord blood and $2.03 \pm 0.34 \mathrm{mU} / \mathrm{mL} / 10^{6}$ cells $(2.03 \pm 0.34 \mathrm{U} / \mathrm{L})$ from adult peripheral blood. Epo accumulation by Hep $3 \mathrm{~B}$ cells increased 6- to 7-fold when cells were grown in $1 \%$ oxygen. Accumulation of Epo by macrophages did not significantly increase under these conditions.

\section{DISCUSSION}

In the fetus, the liver macrophage appears to be the primary source of Epo production $(4,5,9)$. At some point between the last trimester of gestation and the 1st postnatal mo of life, production of Epo shifts from the liver macrophage to peritubular cells in the kidney. The reason for this change in site of production is unknown.

Production of Epo by the fetal liver and postnatal kidney appears to be stimulated by similar degrees of hypoxemia $(9,10)$; however a greater degree of hypoxemia is required for Epo production by adult liver macrophages. Both physiologic (hypoxia) and nonphysiologic (cobalt, nickel) stimuli appear to regulate production of Epo by increasing Epo gene expression (10,11). Using an adult murine model. Rich (12) determined that bone marrow macrophages could produce Epo. The researcher also determined that macrophages were responsive to changes in oxygen tension and postulated that the macrophage could act as a regulator of erythropoiesis under steady state conditions.

Infants born prematurely fail to increase Epo production significantly during anemia despite an apparent need for improved tissue oxygenation ( $1-3)$. It is unknown whether preterm infants rely on Epo production from liver macrophages, renal peritubular cells, or a combination of the two. The results of this study show that Epo mRNA and protein production appears to be intact in macrophages isolated from the cord blood of preterm infants. Although blood macrophages are easily accessible, they are an imperfect model for tissue macrophage function; whether these cells reflect the ability of liver macrophages to produce Epo in vivo remains to be determined. In addition, these macrophages did not respond to $1 \%$ oxygen to the same degree as murine macrophages isolated from bone marrow (12). This finding may reflect a species difference or a cellular microenvironmental factor not present in vitro.

We speculate that because macrophages from preterm infants produce Epo to the same extent as term infants and adults do, it is doubtful that the anemia of prematurity is due to defective Epo production by macrophages. On this basis, we postulate that the defect involves a delay in shifting the anatomic site of Epo production from the liver to peritubular cells in the kidney. Studied aimed at determining the regulation of Epo gene expression in developing renal peritubular cells may help further clarify the molecular cause of the anemia of prematurity.

Acknowledgments. The authors thank Karen Osborne, R.N.. Dixie Hunter, R.N., and Shawna Baker, R.N., for cord blood sample collection.

\section{REFERENCES}

1. Stockman JA III 1977 Anemia of prematurity. Clin Perinatol 4:239-257

2. Bifano EM. Smith F, Borer J 1992 Relationship between determinants of oxygen delivery and respiratory abnormalities in preterm infants with anemia. J Pediatr 120:292-296

3. Brown MS, Garcia JF. Phibbs RH, Dallman PR 1984 Decreased response of plasma immunoreactive erythropoietin to "available oxygen" in anemia of prematurity. J Pediatr 105:793-798

4. Zanjani ED, Poster J, Burlington H, Mann LI. Wasserman LR 1977 Liver as primary site of erythropoietin formation in the fetus. J Lab Clin Med 89:640644

5. Gruber DF, Zucali JR, Mirand EA 1977 Identification of erythropoietin producing cells in fetal mouse liver cultures. Exp Hematol 5:392-398

6. Holbrook ST, Ohls RK, Schibler KR. Yang Y-C. Christensen RD 1991 Effect of interleukin-9 on clonogenic maturation and cell-cycle status of fetal and adult hematopoietic progenitors. Blood 77:2129-2134

7. Goldberg MA, Dunning SP, Bunn HF 1988 Regulation of the erythropoietin gene: evidence that the oxygen sensor is a heme protein. Science 242:14121415

8. Chomczynski P. Sacchi N 1987 Single-step method of RNA isolation by acid guanidinium thiocyanate-phenol-chloroform extraction. Anal Biochem 162:156-159

9. Flake AW, Harrison MR. Adzick NS. Zanjani ED 1987 Erythropoietin production by the fetal liver in an adult environment. Blood 70:542-545

10. Bondurant MC, Koury MJ 1986 Anemia induces accumulation of erythropoitin mRNA in the kidney and liver. Mol Cell Biol 6:2731-2733

11. Schuster SJ, Badiavas EV, Costa-Giomi P. Weinmann R, Erslev AJ. Caro J 1989 Stimulation of erythropoietin gene transcription during hypoxia and cobalt exposure. Blood 73:13-16

12. Rich IN 1986 A role for the macrophage in normal hemopoiesis. II. Effect of varying physiological oxygen tensions on the release of hemopoietic growth factors from bone-marrow-derived macrophages in vitro. Exp Hematol 14:746-751 